\title{
MENGAWAL KESEHATAN KELUARGA MELALUI PEMILIHAN DAN PENGOLAHAN PANGAN YANG TEPAT
}

\author{
Riana Frisca Siahaan* \\ Surel: rianafriskasiahaan@gmail.com
}

\begin{abstract}
Every day humans would need to eat. How many human activities concerned with eating said, would be a very long list. But from the dining events will be the question. Is it a healthy food? And even a healthy diet? Of course the answer will vary. Depending on the level of nutrition knowledge and awareness of the person. For that it is important knowledge of nutrition, so that can be applied in everyday life. Especially for women. Why? Because usually, the women who have the opportunity and the ability to better manage their family consumption. Although it is possible, men also have the ability in this regard. For women, it would certainly be an honor in itself. Due to the provision of healthy food in the family, God willing, the condition of every member of the family would be more secure. With good body condition, it will be able to support them in order to excel. Thus, the role of women is important to support the success of each member of the family.
\end{abstract}

Keywords: healthy food, diet

\section{PENDAHULUAN}

S etiap manusia pasti ingin hidup bahagia. Tapi tahukah Anda bahwa untuk menuju bahagia itu salah satu kunci pentingnya hidup sehat. Coba bayangkan ketika Anda sakit gigi. Apakah Anda bisa tertawa gembira dan bahagia. Jawabnya tentu saja tidak. Itu baru sakit gigi. Bayangkan jika sakitnya lebih serius dari itu, tak hanya Anda sendiri. Keluarga dan sahabat pasti ikut bersedih. Oleh karen ${ }^{1}$ a itu, selalu berusahalah untuk tetap sehat. Untuk mencapai kesehatan yang prima, kita sebagai anggota keluarga memerlukan lingkungan hidup yang sehat,

*Dra. Riana Frisca Siahaan, M.Pd. Dosen Jurusan PKK FT UNIMED terutama lingkungan tempat keluarga berinteraksi, yaitu rumah harus menjadi lingkungan yang nyaman, menyenangkan, dan menyehatkan bagi keluarga. Jika rumah dan sekitarnya selalu terjaga kebersihan dan kesehatan nya, maka keluarga akan mudah menjalankan pola hidup sehat. terapkan pola makan sehat. Makanan memegang peranan sangat vital dalam menjaga kesehatan keluarga. Jika makanan yang dikonsumsi sudah sehat baik dari segi gizi maupun kebersihannya maka kesehatan sekeluarga pun akan terjamin kesehatannya. Hindari makanan tinggi lemak, gula, dan garam. Konsumsi tiga komponen itu secukupnya saja dan jangan berlebih. 
Riana Frisca Siahaan, Mengawal Kesehatan Keluarga.... Hal. 57 - 64

Konsumsilah makanan secara bervariasi dan berimbang mulai dari sayur, buah, susu hingga makanan pokok yang bervariasi.

\section{PEMBAHASAN}

\section{Apa perlunya pola makan sehat}

Seperti telah dijelaskan di atas, bahwa dengan pola makan yang sehat, kondisi fisik tubuh akan lebih terjamin sehingga tubuh akan dapat melakukan aktifitasnya dengan baik pula. Dengan tubuh yang sehat, orang akan lebih bersemangat untuk bekerja, berpikir dan akan lebih produktif. Begitu pula halnya dengan anak-anak. Anak yang sehat akan tampak lebih lincah, kreatif dan bersemangat belajar. Hal ini karena kebutuhan tubuh dapat dipenuhi dengan baik sehingga organ-organ tubuh akan melakukan fungsinya dengan baik pula. Sebaliknya, bila tubuh kekurangan suatu zat gizi tertentu, maka daya tahannya juga akan menurun. Kemampuan kerjanya melemah. Dan bila berkelanjutan akan dapat menimbulkan penyakit yang berbahaya. Jangan sampai lupakan pula kondisi kesehatan si ibu itu sendiri. Terutama bagi ibu yang sedang hamil dan menyusui. Kebutuhannya lebih banyak dibanding kondisi biasa. Namun bukan berarti kebutuhannya menjadi dua kali lipatnya. Bagaimana kondisi si ibu akan sangat berpengaruh pada bayi. Juga bagi yang tidak sedang hamil, sebaiknya jangan terobsesi 


\begin{abstract}
memperbaiki sel-sel yang rusak, dapat dipecah untuk menghasilkan energi dan sebagainya. Agar dapat diperoleh kandungan protein yang lengkap, maka perlu untuk mengkombinasikan sumber pangan, dari bahan hewani dan nabati. Kebutuhan protein untuk orang dewasa untuk diet barat menurut FAO/WHO sekitar $0,8 \mathrm{~g} / \mathrm{kg}$ berat badan. Untuk orang Indonesia dewasa diperkirakan sekitar $0,9 \mathrm{~g} / \mathrm{kg}$ berat badan (Puslitbang Gizi). Bahan makanan yang banyak mengandung protein misalnya telur, susu sapi, daging sapi, ayam, kedelai, dan lain-lain.
\end{abstract}

c) Lemak merupakan bahan pangan berenergi tinggi karena setiap gramnya memberi lebih banyak energi daripada karbohidrat atau protein. Lemak merupakan cadangan energi yang disimpan dalam jaringan adipose.

d) Vitamin merupakan zat-zat gizi yang dibutuhkan dalam jumlah sangat sedikit. Vitamin-vitamin tersebut esensial dalam arti tidak dapat disintesis oleh jaringan tubuh manusia semuanya atau dalam jumlah yang cukup untuk memenuhi kebutuhan dalam kondisi

normal.

Berdasarkan kelarutannya, vitamin dibagi menjadi dua. Yaitu vitamin yang larut dalam air (vitamin B dan C) dan yang larut dalam lemak (vitamin A, D, E, K) Contoh-contoh bahan makanan yang mengandung vitamin tsb di antaranya:

- Vitamin B misalnya kacang, telur, bijibijian, hati, dll

- Vitamin C misalnya jeruk, tomat, kubis, buah-buahan, dll

- Vitamin A misalnya wortel, hati, minyak ikan, dll

- Vitamin D misalnya minyak ikan, telur

- Vitamin E misalnya sayur-sayuran hijau, minyak, dll

- Vitamin K misalnya daun hijau, sayursayuran, keju, kuning telur.

e) Mineral juga merupakan unsur yang diperlukan tubuh. Mineral yang dibutuhkan tubuh secara umum dapat dibagi menjadi dua, yaitu makro mineral dan mikro mineral. Makro mineral yang dibutuhkan oleh tubuh yaitu $\mathrm{Ca}, \mathrm{P}$ (phospor), S (belerang), K (kalium), $\mathrm{Na}$ (natrium), 
$\mathrm{Cl}$ (chlor) dan $\mathrm{Mg}$ (magnesium). Banyak didapatkan dari keju, kerang-kerangan, garam meja, kacang-kacangan , dll. Sedangkan mikromineral yang dibutuhkan tubuh misalnya Fe, Flour, Zn (seng), Si (silicon), dll. Namun di antara mikromineral tersebut, Fe adalah mikromineral yang paling banyak dalam tubuh manusia.

f) Air bukan merupakan salah satu zat gizi. Namun sangat dibutuhkan oleh tubuh. Sekitar $70 \%$ komponen massa tubuh orang dewasa adalah air. Karena itu usahakan untuk mengkonsumsi air 2-2,5 liter per hari untuk orang dewasa.

g) Zat nabati sekunder atau fungsional

Sekarang ini telah diketahui bahwa di samping zat-zat makanan yang telah diulas di atas terdapat pula zat-zat lainnya di dalam bahan makanan nabati (asal dari tanaman) yang tidak mempunyai sifat sebagai zat gizi, namun sangat diperlukan oleh tubuh karena mengkondisikan tubuh untuk terhindar dari berbagai macam penyakit.

Kelompok zat ini dinamakan zat nabati sekunder atau fungsional dan terdapat terutama pada buah dan sayur. Zatzat sekunder ini jumlahnya kecil sekali, namun sudah cukup untuk menghasilkan efek positif yang sangat besar terhadap kesehatan. Di samping sebagai sumber zat nabati fungsional, bahan pangan nabati juga mengandung serat kasar yang meskipun tidak menyumbang energi namun mutlak diperlukan untuk proses pencernaan. Serat kasar akan dikeluarkan kembali oleh tubuh dalam bentuk feses (kotoran) saat buang air besar. Jadi, makanan kita hendaknya tidak hanya mengenyangkan dan mendatangkan energi, namun juga mengandung zat-zat gizi lengkap sesuai kebutuhan tubuh serta zat nabati fungsional dan serat.

2. Pola makan sehat. Pedoman praktis untuk mengatur makanan sehari-hari yang seimbang tertuang dalam 13 pesan dasar sebagai berikut (Pedoman Umum Gizi Seimbang, Direktorat Gizi Masyarakat, RI): 
a) Makanlah aneka ragam makanan

b) Makanlah makanan untuk memenuhi kecukupan energi

c) Makanlah makanan sumber karbohidrat setengah dari kebutuhan energi

d) Batasi konsumsi lemak dan minyak sampai seperempat dari kebutuhan energi

e) Gunakan garam beryodium

f) Makanlah makanan sumber zat besi

g) Berikan ASI saja kepada bayi sampai umur empat bulan

h) Biasakan makan pagi

i) Minumlah air bersih, aman yang cukup jumlahnya

j) Lakukan kegiatan fisik dan olah raga secara teratur

k) Hindari minum minuman beralkohol

I) Makanlah makanan yang aman bagi kesehatan

m) Bacalah label pada makanan yang dikemas.

Sedangkan pada masyarakat Jepang, ada beberapa anjuran untuk menjaga kesehatan ini (Dept. Kesehatan, Tenaga Kerja dan Kesejahteraan Jepang, 2002): a) Bila badan dan hati merasa puas maka akan dapat menciptakan kesehatan

b) Makanlah makanan yang bergizi lengkap, karbohidrat, lemak, protein, mineral, vitamin dan juga air

c) Makanlah tiga kali sehari dengan porsi yang seimbang

d) Makanlah cukup sayuran dan buah buahan

e) Minumlah susu

f) Makan jangan berlebihan

g) Jangan lupa makan pagi

h) Setelah makan jangan langsung tidur

i) Jangan banyak garam, bahan tambahan makanan, makanan instant dan bumbu penyedap

j) Usahakan ragam makanan 30 jenis dalam 1 hari

k) Jangan lupa olahraga

1) Diet yang aman

m) Kunyahlah makanan dengan baik dan jangan terburu-buru

n) Lakukan olahraga dengan teratur

o) Makanlah bersama keluarga dengan gembira

\section{Pengecekan Pola Makan}

Ada cara sederhana untuk mengecek apakah pola makan selama ini sudah cukup baik atau belum, yaitu dengan menggunakan metode Body Mass Index (BMI). berat badan (dalam kilogram) 
$\mathbf{B M I}=$

\section{kuadrat tinggi badan (dalam meter)}

Indeks Massa Tubuh (IMT)

atau Body Mass Index (BMI) merupakan alat atau cara yang sederhana untuk memantau status gizi orang dewasa, khususnya yang berkaitan dengan kekurangan dan kelebihan berat badan. Berat badan kurang dapat meningkatkan resiko terhadap penyakit infeksi, sedangkan berat badan lebih akan meningkatkan resiko terhadap penyakit degeneratif. Oleh karena itu, mempertahankan berat badan normal memungkinkan seseorang dapat mencapai usia harapan hidup yang lebih panjang. Pedoman ini bertujuan memberikan penjelasan tentang cara-cara yang dianjurkan untuk mencapai berat badan normal berdasarkan IMT dengan penerapan hidangan seharihari yang lebih seimbang dan cara lain yang sehat. Untuk memantau indeks massa tubuh orang dewasa digunakan timbangan berat badan dan pengukur tinggi badan.

\section{IMT Sebagai Alat Pemantau Berat Badan}

\footnotetext{
Dengan IMT akan diketahui apakah berat badan seseorang dinyatakan normal, kurus atau gemuk. Penggunaan IMT hanya untuk orang dewasa berumur $>18$ tahun dan tidak dapat diterapkan pada bayi, anak, remaja, ibu hamil,
}

dan olahragawan. Batas ambang IMT ditentukan dengan merujuk ketentuan FAO/WHO, yang membedakan batas ambang untuk laki-laki dan perempuan. Disebutkan bahwa batas ambang normal untuk laki-laki adalah: 20,1 - 25,0; dan untuk perempuan adalah : 18,7 -23,8. Untuk kepentingan pemantauan dan tingkat defisiensi kalori ataupun tingkat kegemukan, lebih lanjut FAO/WHO menyarankan menggunakan satu batas ambang antara laki-laki dan perempuan. Ketentuan yang digunakan adalah menggunakan ambang batas laki-laki untuk kategori kurus tingkat berat dan menggunakan ambang batas pada perempuan untuk kategori gemuk tingkat berat. Untuk kepentingan Indonesia, batas ambang dimodifikasi lagi berdasarkan pengalaman klinis dan hasil penelitian di beberapa negara berkembang. Pada akhirnya diambil kesimpulan, batas ambang IMT untuk Indonesia adalah sebagai berikut (Direktorat Gizi Masyarakat, $\mathrm{RI})$ :

\begin{tabular}{|l|l|l|}
\hline & \multicolumn{1}{|c|}{ Katagori } & \multicolumn{1}{c|}{ IMT } \\
\hline Kurus & $\begin{array}{l}\text { Kekurangan } \\
\text { berat } \\
\text { badan tingkat } \\
\text { berat }\end{array}$ & $\begin{array}{l}\text { Kurus } \\
<17,0\end{array}$ \\
& & \\
\hline
\end{tabular}

p-ISSN: 1693-1157, e-ISSN: 2527-9041 


\begin{tabular}{|c|c|c|}
\hline Kurus & $\begin{array}{l}\text { Kekurangan } \\
\text { berat } \\
\text { badan tingkat } \\
\text { ringan }\end{array}$ & $\begin{array}{ll}17,8 & - \\
18,4 & \end{array}$ \\
\hline Normal & & $\begin{array}{l}18,5- \\
25,0\end{array}$ \\
\hline Gemuk & $\begin{array}{l}\text { Kelebihan } \\
\text { berat } \\
\text { badan tingkat } \\
\text { ringan }\end{array}$ & $\begin{array}{l}25,1- \\
27,0\end{array}$ \\
\hline Gemuk & $\begin{array}{l}\text { Kelebihan } \\
\text { berat } \\
\text { badan tingkat } \\
\text { berat }\end{array}$ & $>27,0$ \\
\hline
\end{tabular}

Kategori seseorang menurut IMTnya :

1. IMT < 17,0: keadaan orang tersebut disebut kurus dengan kekurangan berat badan tingkat berat atau Kurang Energi Kronis (KEK) berat.

2. IMT 17,0 - 18,4: keadaan orang tersebut disebut kurus dengan kekurangan berat badan tingkat ringan atau KEK ringan.
3. IMT 18,5 - 25,0: keadaan orang tersebut termasuk kategori normal.

4. IMT 25,1-27,0: keadaan orang tersebut disebut gemuk dengan kelebihan berat badan tingkat ringan.

5. IMT $>27,0$ : keadaan orang tersebut disebut gemuk dengan kelebihan berat badan tingkat berat

\section{Contoh cara menghitung IMT:}

Eko dengan tinggi badan $148 \mathrm{~cm}$ dan berat badan $38 \mathrm{~kg}$, maka IMT-nya:

$$
\underline{38 \mathrm{~kg}}=17,3
$$

$(14,8 \times 14,8) \mathrm{m} 2$

Status gizi Eko adalah kurus tingkat ringan. Eko dianjurkan menaikkan berat badan sampai menjadi normal antara 41 - $54 \mathrm{~kg}$ dengan IMT 18,5 25,0 .

Seseorang yang termasuk kategori kekurangan berat badan tingkat ringan (KEK ringan) sudah perlu mendapat perhatian untuk segera menaikkan berat badan.

Opong dengan tinggi badan $159 \mathrm{~cm}$, mempunyai berat badan $70 \mathrm{~kg}$. Maka IMT

Opong adalah :

$$
=27,7
$$


Riana Frisca Siahaan, Mengawal Kesehatan Keluarga.... Hal. 57 - 64

$$
(15,9 \times 15,9) \mathrm{m} 2
$$

Berarti status gizi Opong adalah gemuk tingkat berat, dan Opong dianjurkan menurunkan berat badannya sampai menjadi 47 - $63 \mathrm{~kg}$ agar mencapai berat badan normal (dengan IMT 18,5 - 25,0).

Seseorang dengan IMT > 25,0 harus berhati-hati agar berat badan tidak naik. Dianjurkan untuk menurnkan berat badannya sampai dalam batas normal.

\section{PENUTUP}

Dengan adanya pembahasan ini dapat menjadi bahan masukan utuk memberikan makan yang sehat dan terkontrol sehingga keluarga merasa aman dalam mengkomsumsi makanan.

Mudah-mudahan bermanfaat. Khususnya bagi para wanita, para ratu dapur, antarkan keluarga menuju kesuksesan dengan diawali dari pola makan yang sehat

\section{DAFTAR PUSTAKA}

Pedoman Umum Gizi Seimbang (PUGS), Direktorat Gizi Masyarakat, RI.

Pedoman Praktis Memantau Status Gizi Orang Dewasa, Direktorat Gizi Masyarakat, RI.
Departemen Kesehatan , Tenaga kerja dan Kesejahteraan Jepang, 2002. (bahan pustaka dalam edisi bahasa jepang).

Studi bahan pangan bidang science dan technology, Jepang. 2000. (bahan pustaka dalam bahasa Jepang).

Home Page Terumo Corporation, japan, 2001.

Nutritional Biochemistry and Metabolism. Maria C.Linder. 1992

Seminar Nasional Jepang mengenai Ukuran Berat Badan dan Lemak Tubuh, 1999. (Bahan Pustaka dalam bahasa Jepang 